\title{
TEST TOLERANSI GLUKOSA ORAL PADA SUBJEK DENGAN BERAT BADAN BERLEBIH
}

\author{
Agus Santosa \\ Departemen Keperawatan Medikal Bedah, Fakultas IImu Kesehatan, Universitas Muhammadiyah Purwokerto, \\ Jawa Tengah \\ Email : agussantosa@ump.ac.id
}

\begin{abstract}
ABSTRAK
Latar Belakang: Diabetes melitus sering tidak terdiagnosa karena perjalanan penyakit ini berlangsung cukup lama. Perlu dilakukanya skrining rutin diabetes sejak umur 45 tahun, dengan adanya deteksi dini dan pengobatan yang tepat dapat memperlambat perkembangan kondisi prediabetes menjadi diabetes melitus.

Tujuan: Penelitian ini bertujuan untuk mengetahui hasil tes toleransi glukosa oral pada subjek dengan berat badan berlebih

Metode: Penelitian ini merupakan penelitian deskriptif dengan pendekatan survey. Lokasi penelitian berada di wilayah Puskesmas Kembaran I Kecamatan Kembaran Kabupaten Banyumas dari Juli-September 2017. Populasi dalam penelitian ini adalah seluruh responden yang berusia $>30$ tahun dengan berat badan berlebih. Sampel penelitian ini berjumlah berjumlah 68 respenden. Instrument penelitian yang digunakan adalah, timbangan injak, metline pengukur tinggi badan dan gluometer. Data dianalisis dengan menggunakan analisis deskriptif sederhana. Hasil: Hasil penelitian menunjukkan rata-rata IMT responden sebesar $27,6 \mathrm{~kg} / \mathrm{m} 2$ yang seluruhnya masuk dalam kategori obesitas. Kadar gula darah hasil TGT menunjukkan nilai rata-rata sebesar $147,6 \mathrm{mg} / \mathrm{dl}$ dan masuk dalam kategori prediabetes. Hasil penelitian menemukan dari sebanyak 68 responden dengan berat badan berlebih/obesitas sebanyak $79,4 \%$ hasil TGT- nya dinyatakan Prediabetes sedangkan $20,6 \%$ dinyatakan Normal.

Kesimpulan: Pada seseorang dengan berat badan berlebih, hasil test toleransi glukosa oralnya sebagian besar masuk pada kategori prediabetes.
\end{abstract}

Kata Kunci: OTGT, IMT, Diabetes Melitus

\section{PENDAHULUAN}

Data Dinas Kesehatan Kabupaten Banyumas (2015) diketahui bahwa jumlah penderita DM sebanyak 7738 penderita. Kejadian DM tertinggi di Wilayah Kerja Puskesmas Kembaran I sebanyak 454 kasus $(5,8 \%)$, tertinggi kedua di Wilayah Kerja Puskesmas Sokaraja II sebanyak 428 kasus $(5,5 \%)$, tertinggi ketiga di Wilayah Kerja Puskesmas Kembaran II sebanyak 417 kasus $(5,3 \%)$ dan kejadian terendah di Wilayah Kerja Puskesmas Sumbang II sebanyak 35 kasus $(0,5 \%)$.

Pada tingkat Nasional, Kejadian diabetes mellitus juga mengalami kenaikan pada tahun ke tahun. Laporan RISKESDAS 2013 ada kenaikan presentase masyarakat terdiagnosis diabetes dari $1.5 \%$ pada tahun 2007 menjadi $2.1 \%$ di tahun 2013 .

Jumlah seseorang yang mengalami obesitas di Indonesia juga terus bertambah setiap tahunnya. Di tahun 1999 prevalensi obesitas berkisar antara 0.7-1.1\% sedangkan pada tahun 2004 jumlahnya meningkat menjadi 4.3-5.3\% (Rimbawan, 2004). Tercatat 1,5 juta orang mengalami obesitas selama tiga tahun terakhir yaitu kurun waktu antara 2007-2009, sebanyak orang dewasa (ADA, 2010).

Dari data tersebut menurut penelitian Himpunan Studi Obesitas Indonesia jumlah prevalensi obesitas dialami oleh pria dewas yaitu $9.16 \%$, sedangkan untuk wanita jumlahnya lebih besar lagi yaitu mencapai 
$11.2 \%$.

Keadaan hiperglikemia yang terus menerus akan menyebabkan banyak komplikasi diberbagai system. Menurut data kematian akibat diabetes setiap harinya didunia mencapai 3160 kematian (Misnadierly, 2007).

Indeks masa tubuh (IMT) seringkali digunakan untuk menilai status gizi seseorang, selain itu IMT juga bisa digunakan untuk menilai status berat badannya, apakah masuk kategori normal, kurang atau masuk obesitas (Soegondo, 2011). Hasil studi memperkirakan $\pm 12 \%$ seseorang dengan IMT $27 \mathrm{~kg} / \mathrm{m} 2$ terdiagnosis mengalami diabetes mellitus tipe 2. Tentunya tidak hanya karena factor berat badan saja, namun factor-faktor lain seperti lingkungan dan gaya hidup yang tidak sehat sserta kurangnya aktivitas fisik memiliki andil sebagai pemicu penyakit tersebut.

Sekitar 70\% seseorang yang di diagnose menderita diabetes memiliki berat badan kategori overweight serta mengalami penurunan toleransi glukosa (Syahbudin, 2013). Peningkatan berat badan dapat dijadikan prediktor timbulnya penyakit diabetes tipe 2, peningkatan berat badan lebih dari $>20 \mathrm{~kg}$ pada umur $\geq 18$ tahun berpeluang 12kali mengalami diabetes dan risiko meningkat menjadi 61kali lebih besar jika indeks masa tubuhnya diatas $35 \mathrm{~kg} / \mathrm{m}$.

Penelitian ini bertujuan untuk meneliti sejauhmana keadaan obesitas pada seseorang berdampak pada hasil tes toleransi glukosanya. Dari hasil tes toleransi glukosa tersebut dapat disimpulkan apakah mereka yang memiliki berat badan berlebih masuk dalam kateori normal, prediabetes dan diabetes melitus.

\section{METODE}

Penelitian ini merupakan penelitian bersifat deskriptif, dengan pendekatan survey (Notoatmodjo, 2010). Lokasi penelitian berada di wilayah Puskesmas Kembaran I Kecamatan Kembaran Kabupaten Banyumas. Waktu penelitian Juli-September 2017

Populasi dalam penelitian ini adalah seluruh responden yang berusia $>30$ tahun dengan berat badan berlebih berdasarkan pengukuran Indek Masa Tubuh (IMT), tidak memiliki gejala diabetes, dan riwayat keluarga diabetes. Sampel penelitian yang berhasil dikumpulkan berdasarkan kriteria inklusi berjumlah 68 responden.

Cara pengumpulan data dalam penelitian dengan mengukur IMT terlebih dahulu untuk mengetahui status obesitas responden, selanjutnya dilakukan Tes Toleransi Glukosa (TGT) dengan cara responden dianjurkan puasa minimal 8 jam, selanjutnya responden diberikan larutan glukosa 75 gramilarutkan dalam air $250 \mathrm{~mL}$ dan diminum, setelah 2 jam gula darah diukur dengan menggunakan glucometer (Supariasa, 2012). Data IMT dan gula darah hasil TGT dianalisis dengan menggunakan analisis deskriptif sederhana (Hidayat, 2007).

\section{HASIL}

Responden dalam penelitian ini seluruhnya masuk dalam kategori obesitas dengan rata-rata IMT sebesar $27,6 \mathrm{~kg} / \mathrm{m} 2$, IMT terendah sebesar $25,3 \mathrm{~kg} / \mathrm{m}^{2}$ dan tertinggi sebesar $32,5 \mathrm{~kg} / \mathrm{m}^{2}$. Kadar gula darah hasil TGT menunjukkan nilai rata-rata sebesar 147,6 mg/dl dan masuk dalam 
kategori prediabetes, dengan kadar gula darah minimal $90 \mathrm{mg} / \mathrm{dl}$ dan gula darah maksimal $168 \mathrm{mg} / \mathrm{dl}$.

Hasil penelitian menemukan dari sebanyak 68 responden dengan berat badan berlebih/obesitas sebanyak $79,4 \%$ hasil TGTnya dinyatakan Prediabetes sedangkan 20,6\% dinyatakan Normal (gambar 1).

\section{PEMBAHASAN}

Hasil penelitian ini menunjukan bahwa semakin gemuk seseorang maka akan semakin besar presentase seseorang terkena prediabetes. Hal ini dibuktikan dengan hasil TGT yang menunjukkan $79 \%$ responden dengan obesitas mengalami prediabetes. Orang dengan IMT berlebih memiliki risiko DM lebih besar dibandingkan risiko penyakit lain (Gill, T, 2012).

Derajat obesitas dan lamanya seseorang mengalami obesitas juga mempengaruhi terjadinya diabetes melitus tipe 2 (Soegondo, 2010). Terdapathubungan yang bermakna antara obesitas dengan resiko kejadian DM (National Health and Medical Research Council, 2013). Mengendalikan berat badan sangat penting dilakukan dalam menjaga diri agar tidak menderita penyakit diabetes ataupun mencegah prediabetes menjadi diabetes mellitus, karena peningkatan gula darah pada seseorang seiring dengan peningkatan indeks masa tubuh (Guyenet, 2012).

Obesitas pada seseorang akan mempengaruhi peninkatan hormone resistin, hormone resistin sendir kepanjangan dari ("resistance to insulin"), hormone tersebut berperan sebagai sebagai trigger terhadap terjadinya resistensi insulin (Berger, 2001). Resistensi insulin yang terjadi seseorang yang obesitas kemudian mengakibatkan penurunan kerja insulin pada jaringan otot sehingga menyebabkan glukosa sulit memasuki sel, dan akhirnya glukosa tetap berada di dalam darah (Clare, 2007).

Pada keadaan obesitas juga terjadi penurunan ekspresi adiponektin secara signifikan (Nigro et al, 2014). Konsentrasi adiponektin serum juga ditemukan lebih rendah pada pasien diabetes tipe 2 diabndingkan non diabetes (Park et al, 2008). Adiponektin adalah sitokin yang spesifik pada jaringan adiposa memiliki struktur yang menyerupai collagen VIII, Collagen $X$ dan complement component C1q. Adiponectin mempengaruhi sensitivitas insulin dengan cara meningkatkan fosforilasi tirosin di reseptor insulin dan insulin receptor substrate di sel otot. Hal ini akan mengurangi konsentrasi asam lemak di dalam sirkulasi dan mengurangi kadar trigliserida di dalam otot dan hati (Havel, 2004). Penurunan adiponectin berakibat penurunan sensitivitas insulin hepatik dan perifer (Cnop et al, 2003). 


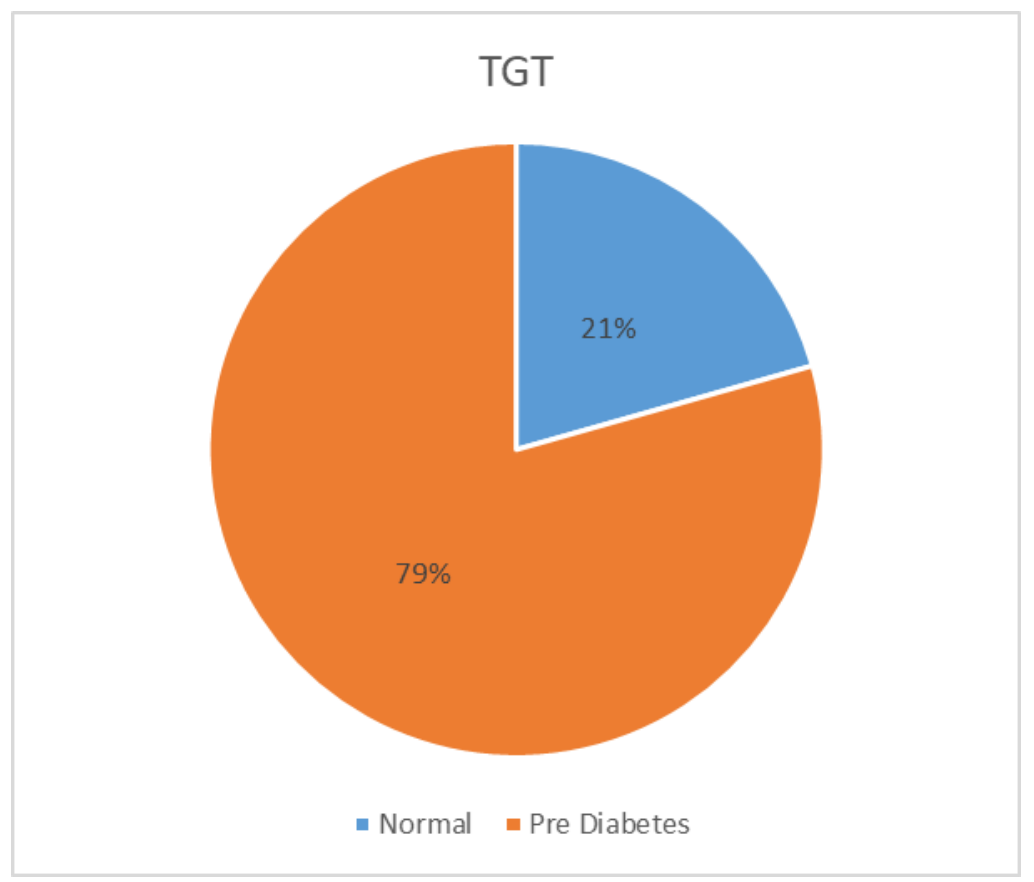

Gambar 1. Hasil Tes Toleransi Glukosa

Pada keadaan obesitas juga terjadi peningkatan TNF- $\alpha$. TNF- $\alpha$ adalah pemicu kuat adipositokinin proinflamasi seperti IL-, MCP-leptin dan PAI-. TNF- $\alpha$ terlibat dalam proses inflamasi pada pasien obesitas. Peningkatan TNF-a pada pasien obesitas menunjukkan hubungan langsung timbulnya resistensi insulin (Zhang et al, 2011).

Terjadinya resistensi insulin ini menyebabkan glukosa yang beredar di dalam darah tidak mampu untuk masuk ke dalam sel, sehingga kadar gula di dalam darah menjadi lebih tinggi dari normal (Suyono, 2011). Hiperglikemia pada penderita diabetes melitus juga berkaitan erat dengan metabolisme lemak. Lemak yang memiliki tugas utama untuk menyimpan energi dalam bentuk trigliserida melalui proses lipogenesis yang terjadi sebagai respons terhadap kelebihan energi dan memobilisasi energi melalui proses lipolisis sebagai respons terhadap kekurangan energi. Pada keadaan normal, kedua proses ini diregulasi dengan ketat (Sudoyo et al, 2009).

\section{KESIMPULAN DAN SARAN}

Sebanyak $79 \%$ responden dengan obesitas hasil TGT-nya mengindikasikan mengalami prediabetes. Perlu adanya penyuluhan tentang pengendalian berat badan agar resiko prediabetes yang mengarah kepada diabetes mellitus bisa dicegah.

\section{DAFTAR PUSTAKA}

American Diabetes Association. (2010). Standar of medical care in diabetes, diabetes care. Retrieved from http://care.diabetesjournals.org/content/ 33/Supplement_1/S11.full.pdf.

Berger A. (2001). Resistin: a new hormone that links obesity with type 2 diabetes. BMJ : British Medical Journal. 322(7280):193.

Clare-Salzler, M.J., Crawford, J.M., \& Kumar, V. (2007). Pankreas. Dalam: Kumar, V., Cotran R.S., Robbins, S.L. Buku Ajar Patologi. Edisi 7. Jakarta: EGC

Cnop M, Havel PJ, Utzschneider KM, et al. 
(2003). Relationship of adiponectin to body fat distribution, insulin sensitivity and plasma lipoproteins: evidence for independent roles of age and sex. Diabetologia. 46(4):459-469. doi:10.1007/s00125-003-1074-z

Departemen Kesehatan RI. (2013). Riset Kesehatan Dasar. Badan Penelitian dan Pengembangan Kesehatan. Jakarta.

Dinkes Jateng. (2013). Profil kesehatan Jawa Tengah tahun 2013. Semarang: Dinkes Jateng.

Gill, T. (2002) Importance of Preventing Weight Gain in Adulthood. Asia PasificJournal Clinical Nutrition, 11, pp. 632-636

Guyenet, Stephan J. Dan Michael W. (2012). Regulation Of Food Intake, Energy Balance, And Body Fat Mass: Implications for the Pathogenesis and Treatment Of Obesity. JClin Endocrinol Metab, Maret 2012,97(3),745-755.

Havel PJ. (2004). Update on Adypocytes Hormones. Regulation of Energy Balance and Carbohydrate/ Lipid Metabolism. Diabetes. 53 (1): S143-S1152.

Hidayat. (2007). Metode Penelitian Keperawatan dan Teknik Analisi Data. Jakarta: Salemba Medika.

Misnadierly. (2007). Obesitas Sebagai Faktor Resiko Berbagai Penyakit. Jakarta: Pustaka Obor Populer.

National Diabetes Education Program. (2011). 4Steps to Control Your Diabetes ForLife, NIH publication: 11 - 5492

Nigro, E., Scudiero, O., Monaco, M. L., Palmieri, A., Mazzarella, G., Costagliola, C., Bianco, A., ... Daniele, A. (2014). New insight into adiponectin role in obesity and obesity-related diseases. BioMed research international, 2014, 658913. doi:10.1155/2014/658913.

Notoatmodjo. S. (2010). Metodologi Penelitian Kesehatan. Jakarta: Rineka Cipta.

Park JY, Kim JW, Kim JM, Han Y, Park SK, Mok JY, Park MK, Lee HJ, Kim DK. (2008). Adiponectin Concentrations in Type 2 Diabetic Patients with or without Metabolic Syndrome. Korean Diabetes J. 32(3):224-235. https://doi.org/10.4093/kdj.2008.32.3.22 $\underline{4}$

Rimbawan dan Siagian, A. (2004). Indeks Glikemik Pangan. Jakarta: Penebar Swadaya.
Soegondo. S, Soewondo. P, Subekti Imam. (2011). Penatalaksanaan Diabetes Melitus Terpadu. Jakarta: FKUI

Subekti, I. (2009). Apa Itu Diabetes; Patofisiologi, Gejala dan Tanda. Jakarta: Balai Penerbit FKUI

Sudoyo AW, Setiyohadi B, Alwi I, Simadibrata M, Setiati S. (2009). Buku Ajar IImu Penyakit Dalam Jilid II edisi V. Jakarta: Interna Publishing

Supariasa, I.D.N., Bakri, B., Fajar, I. (2012). Penilaian Status Gizi. Jakarta: EGC.

Suyono, S. (2011). Patofisiologi Diabetes Melitus dalam buku Penatalaksanaan Diabetes Terpadu sebagai Panduan Penatalaksanaan Diabetes Mellitus bagi dokter maupun edukator diabetes. Jakarta: Fakultas Kedokteran Universitas Indonesia.

Syahbudin, S. (2009). Diabetes Melitus dan Pengelolaannya. Cetakan 2, PusatDiabetes \& Lipid RSUP Nasional Dr. Cipto Mangunkusumo. Jakarta: FKUI.

Zhang, R., Yao, Y., Wang, Y. \& Ren, G. (2011). Antidiabetic Activity of Isoquercetin in Diabetic KK -AyMice, Nutrition \& Metabolism, 8(85) 